Article

\title{
Sustainable Construction Risk Perceptions in the Kuwaiti Construction Industry
}

\author{
Dalya Ismael * and Tripp Shealy \\ Department of Civil and Environmental Engineering, Virginia Tech, Blacksburg, VA 24061, USA; tshealy@vt.edu \\ * Correspondence: dalya88@vt.edu
}

Received: 30 April 2018; Accepted: 1 June 2018; Published: 3 June 2018

check for updates

\begin{abstract}
Sustainable construction is fundamentally different than traditional construction because it requires whole systems thinking, early collaboration across stakeholders, and core principles like reducing resource consumption, eliminating toxins, and applying life cycle costing. Construction professionals unfamiliar with this mindset and approach may perceive sustainable construction as risky. One of the global regions in need of more sustainable construction is the Middle Eastern and North African (MENA) region. The MENA region is one of the fastest developing in the world. However, it is the slowest one in implementing sustainable construction practices. Kuwait, in particular, contributes 53\% more carbon emissions per capita than the United States. To understand how the Kuwaiti construction industry perceives risks associated with more sustainable construction, a survey was developed with 52 risk elements in which 131 industry professionals responded. The results indicate that industry professionals perceive a lack of public awareness as the risk element with the highest probability of occurrence. The risk element with the highest possible negative impact on future projects is designers' and contractors' inexperience with sustainable construction. Other risks were found to include a high initial cost for materials and overall project costs. Educational interventions, changes in risk allocation, and behavioral science to reframe upfront costs as long-term savings are offered as possible solutions.
\end{abstract}

Keywords: sustainable construction; risk perceptions; risk management; Kuwait

\section{Introduction}

Sustainable development goals usually focus on broad problems like climate change, energy reduction, and clean air and water. While these broad objectives are necessary, their abstractness can make it challenging for construction professionals to know how to achieve them [1]. This is because the techniques and approaches that are optimal for specific projects vary depending on the geographic location, regional energy sources, community characteristics, stakeholder priorities, and many other variables. In addition, sustainable construction, which refers to achieving social, financial, and environmental sustainability throughout a building's whole life-cycle [2] requires a higher level of collaboration between stakeholders when compared to traditional construction projects due to increased uncertainty [3,4]. This uncertainty is due to the complexity of project decisions, which are often made using prior held judgments and heuristics $[5,6]$. Without prior experience, the outcomes of sustainable choices can appear risky [7]. When adopting new techniques for sustainable construction, previously held judgments and heuristics must also change.

Currently held judgments and heuristics about sustainable construction do not always represent reality [8]. For example, the long-held perception that sustainable construction costs more financially upfront does not hold true today [9]. Cognitive biases such as risk aversion and status quo bias can lead to these overly generalized assumptions $[10,11]$. Better understanding of these perceptions, 
judgments, and heuristics can add value by offering opportunities to educate, increase awareness, and, most importantly, help stakeholders make more informed project level decisions.

Making more informed project level decisions means knowing what factors cause risk and which risks are worth taking [12]. Sustainable construction can appear overly risky when outcomes of value appear not to align with stated stakeholder objectives [13]. Prior research finds differences in stakeholder objectives can increase risk perceptions [14]. For instance, transaction costs are a real risk for general contractors when adopting sustainable construction practices, but this risk is often not a concern from the owners' perspective [15].

How risk and uncertainties vary between stakeholders, industry sectors (e.g., private or public), and global regions are still not well understood [16]. Risks about sustainable construction are particularly challenging to manage because much of the risk occurs upfront while the value comes later over time. The success of sustainable construction (e.g., eliminating impacts on the environment and natural resources, enhancing the health, well-being and productivity of occupants, creating new economic development, and applying a lifecycle approach during planning) heavily relies on contractors' willingness to adopt this new mindset and associated means and methods [17].

Regions of the world that were early to adopt sustainable design and construction practices continue to lead in global sustainable development. The number of new buildings in the United States certified by the Leadership in Energy and Environmental Design (LEED) rating system has grown exponentially in the last decade [18]. As more countries begin to adopt similar rating systems and tools for industry professionals, these industries will face similar barriers experienced by the United States construction market nearly a decade ago [9,19].

One of the global regions in need of sustainable construction is the Middle Eastern and North African (MENA) region. The MENA region is one of the fastest developing in the world. However, this region is slow in developing and implementing sustainable design and construction practices [20]. An early adopter of sustainable construction in this region who experiences a loss of profits or increased burden may have a lasting negative impact in the region's adoption of sustainable design and construction practices in the future [21]. Therefore, understanding the risks associated with sustainable construction prior to adopting these techniques can have a positive impact on the entire region.

\section{Sustainable Construction in Kuwait and the MENA Region}

Increasing adoption of sustainable construction practices in the MENA region is necessary for global sustainable development goals. For instance, greenhouse gas emissions are not isolated to merely one region or country but have a negative effect globally. In the past 20 years, the MENA region has increased carbon dioxide emissions by around $114 \%$ and per capita by $44 \%$ [22]. While this region currently only contributes approximately $6 \%$ of the world's carbon dioxide emissions, the trend suggests the region will become a larger contributor to global greenhouse gas emissions in the next century [23].

In comparison to its neighboring countries in the MENA region, Kuwait holds the lowest commitment to sustainable construction [20]. Per capita, residents contribute 53\% more carbon dioxide emissions than residents of the United States [22]. This is partly because the country relies on energy-intensive desalination to produce potable water [24] and nearly $85 \%$ of electricity costs are subsidized [20]. Furthermore, Kuwait's construction industry has doubled their annual landfill waste in the past five years [25].

One explanation for the lack of commitment among the construction industry is the lack of awareness. Few professionals have experience in sustainable construction techniques and associated technology [20]. Lack of experience means there are fewer projects that demonstrate the benefits and, therefore, less motivation among industry professionals to try something new [26,27]. When awareness about the benefits of sustainable construction increase, the demand for more sustainable buildings and infrastructure also grow [28]. This demand helps drive further adoption and innovation helping these early adopters of sustainable design and construction reach even higher achievement in the future [29]. 
The lack of political support and incentives to adopt the design and construction techniques that promote sustainability from the Kuwaiti government is likely another reason for slow adoption of sustainable construction. Kuwait engineering design and construction professionals agree that government intervention through new standards and policy is necessary to accelerate adoption [20]. External involvement and additional incentives may help offset perceived risks and encourage market demand.

To help Kuwait and the MENA region more quickly adopt sustainable construction techniques, the purpose of the research reported in this paper is to assess current perceived risks within the industry. Knowing how sustainable construction is perceived can help design interventions, tools, and processes to help this industry overcome these perceived barriers or more efficiently manage them in the future.

\section{Background}

Sustainable construction is fundamentally different than traditional construction [30]. The purpose of sustainable construction is to create and operate a building based on core principles across the building's life cycle. Sustainable construction should reduce resource consumption, reuse resources, integrate recyclable resources, protect nature, eliminate toxins, apply life cycle costing, and focus on quality [31]. Achieving such high standards requires those involved in the design and construction process to "begin with the end in mind" [17]. This means setting specific goals and building features early during the feasibility stage that align with core sustainability principles.

Those involved in the design and construction process must also take a whole systems approach [32]. A whole systems approach encourages the consideration of interrelated components and people to optimize the performance of the entire building rather than an individual part [33]. For example, Rocky Mountain Institute, which is a consulting firm in the United States, uses a whole systems approach to optimize thermal mass of building envelopes and windows and other components to produce the most cost-effective passive building [34]. Whole systems requires establishing common goals that align incentives, encourage mutual learning, and sharing of information across stakeholder groups [35].

Adopting a whole systems approach and applying sustainable practices can appear risky compared to traditional construction especially for those that are new to sustainable construction. A broadly defined risk is the combination of the probability of an event and its outcomes [36]. Risk management is then the process by which risks are identified, quantified, and used to inform decision making and planning future events [37]. Risk management includes the ability to recognize risks with low probability and low impact compared to risks with high probability and high impact. For example, recognizing the likelihood of failure, delay of schedule, or increased cost by changing construction techniques to reduce the disruption of soils or the probability of success in installing more sensors in a building for enhanced monitoring and control.

Without prior experience, for instance, in changing commonly used materials for those with less embodied energy, errors can occur in judgment and lead to overly weighing probabilities of risks [38]. For example, sustainable construction can appear more expensive when construction professionals are unaware of these possible risks and, as a result, assign higher contingencies [15]. The opposite can also be true. The pseudo-certainty effect occurs when a decision maker perceives an outcome as certain while, in fact, it is uncertain [39]. The success of sustainable construction depends on the judgment of perceived risks and the development of an appropriate risk management plan [40,41]. Understanding the unique variation between conventional and sustainable projects is also essential for beginning to develop risk management techniques and interventions for sustainable construction that has neither overweight nor underweight risks.

Perceived risks to sustainable construction continue to emerge globally as developing countries begin to explore and adopt new techniques and technologies [26,27]. Countries in the MENA region like Kuwait that lack prior experience with sustainable construction techniques may fall into a trap of 
assigning higher contingencies, which increases the overall cost of the project and creates negative barriers to more sustainable construction projects in the future [42]. Overlooking possible risks leading to negative outcomes for the project team, also known as the pseudo-certainty effect, is also a possibility, which results in less incentive to adopt new techniques as industry norms in the future. Prior research in the MENA region discuss construction risks (e.g., in Kuwait see Reference [43], the U.A.E. see Reference [44], Qatar see Reference [45], and Bahrain see Reference [46]) but fall short in covering, discussing, or outlining possible risks related to new means and methods that incorporate principles of sustainable construction.

Improved ability for assessing risks can help shift industry professionals' focus to appropriately reduce the risk of failure for sustainable construction [47]. Prior research about sustainable construction practices in developed countries like Australia, the United States, and Europe do outline increased risks and recommendations [26] and novel contract structures to share the risk burden [48]. The lists of possible risks from these prior works were used to develop a survey instrument detailed in the methods section of this paper. The weighting of these risks may be different as a result of cultural values, regional or national economic incentives, and political interests [49]. Therefore, identifying the potential risk factors and weights of perceived probability plays a crucial role in enhancing the performance and accomplishing the successful delivery of the project.

\section{Synthesis of Research about Risks Associated with Sustainable Construction}

Risks associated with sustainable construction were gathered from prior literature and synthesized into categories broadly defined within the design and construction process of new buildings. The purpose of this literature review was to identify potential sustainable risks during a project's life-cycle. The review consisted of an extensive literature search of recently identified sustainable construction risks in other countries including, more specifically, the work from Reference [43] and Reference [46]. Inclusion criteria required research to be within 10 years (articles published from 2005 to 2015) since modern risk management has greatly evolved over the last decade. This review process follows a similar process of prior synthesized literature reviews [50].

More than 20 papers were included and used to develop the synthesized list presented in Table 1. Nine categories and 52 risk elements were organized from the literature. The nine categories include design, management, construction, material, technology, labor and equipment, external factors, finance, and certification. Risk elements associated with design include both inexperience when dealing with sustainable construction and changes as a result of sustainable construction. Management risks are related to design. Management includes risk elements upstream (clients) and downstream (subcontractors) from the general construction process. Lack of communication, lack of dispute resolution, and general planning are particular risk elements that were identified from prior studies $[17,51,52]$. Construction techniques, defects, and inexperience were also included as risk elements in the construction category. The categories material, technology, and labor and equipment include risk elements about prior knowledge, lack of experience, and non-compliance. Cost is always a concern and represented in both the external and finance categories through a lack of market demand and associated with payback period and cost overruns. Project certification was also identified as an incentive for pursuing sustainable construction and a possible barrier [53]. Energy models that do not align with actual energy performance are increasingly problematic in new sustainable buildings [54].

Table 1 was used to develop both the research questions and survey instruments to measure both perceived probability of occurrence and possible impact of these risk elements during construction projects in Kuwait that include sustainable design and construction principles. 
Table 1. Synthesized list of construction risks associated with adopting techniques and technologies that promote sustainability.

\begin{tabular}{|c|c|}
\hline Design & External \\
\hline Design changes during construction [55] & Lack of market demand [56] \\
\hline Slow response to meet design changes [26] & Lack of political support and incentives [49] \\
\hline Design-team inexperience [57] & Lack of public awareness and knowledge [58] \\
\hline Design defects which could result in failure to achieve certification [53] & Uncertain governmental policies [19] \\
\hline Management & Finance \\
\hline Lack of quantitative evaluation tools [59] & Cost estimation inaccuracy [46] \\
\hline Not achieving client expectations [55] & Payback period is too long [60] \\
\hline $\begin{array}{l}\text { Difficulty in the selection of subcontractors who provide sustainable } \\
\text { construction services [51] }\end{array}$ & $\begin{array}{l}\text { Performance problems since sustainable building projects face a } \\
\text { greater potential in failure (causing liabilities) [53] }\end{array}$ \\
\hline Poor interrelationships between supply chain partners [26] & $\begin{array}{l}\text { Increased soft costs due to delays in sustainable building } \\
\text { completion [53] }\end{array}$ \\
\hline Lack of upfront planning by all parties [17] & High cost of sustainable materials and equipment [51] \\
\hline Sustainability measures not considered early by stakeholders [52] & Cost overrun due to lack of sustainable building knowledge [61] \\
\hline Delays in resolving disputes [26] & High initial sustainable construction costs [26] \\
\hline Slow approval processes due to sustainable specifications [26] & Investor cannot fund the high sustainability measure costs [61] \\
\hline \multirow[t]{2}{*}{ Outdated contractual agreements [62] } & Costs of investment in skills development [57] \\
\hline & High sustainable construction premiums [17] \\
\hline Material & Labor and Equipment \\
\hline Unavailability of sustainable building materials [63] & $\begin{array}{l}\text { Handling recycled materials puts construction workers at safety } \\
\text { risks [43] }\end{array}$ \\
\hline Poor material quality [26] & Unavailability of specific equipment [15] \\
\hline Uncertainty in the performance of sustainable materials [59] & Additional responsibilities for construction maintenance [59] \\
\hline Non-complying products and materials [26] & Lack of practical experience [15] \\
\hline Change in material types and specifications during construction [43] & Uncertainty with specialized sustainable equipment [51] \\
\hline Technology & Certification \\
\hline Challenges for operating renewable energy systems [63] & An event that causes the loss of certification [53] \\
\hline Unacceptable performance of modern technologies [61] & $\begin{array}{l}\text { Lower certification than what was expected due to design } \\
\text { defects [53] }\end{array}$ \\
\hline Technological failures [61] & Changing certification procedures [61] \\
\hline Misunderstanding of sustainable technological operations [59] & Loss of financing or losing loans for not achieving certification [53] \\
\hline \multicolumn{2}{|c|}{ Construction } \\
\hline Unforeseen circumstances in execution of the sustainable project [51] & More complex construction techniques [60] \\
\hline Safety issues [61] & Project delay [55] \\
\hline Contractors' inexperience with sustainable buildings [57] & Incremental time caused by sustainable construction [59] \\
\hline Construction defects [53] & \\
\hline
\end{tabular}

\section{Research Objective and Questions}

The objective of the research presented in this paper is to understand what perceived risks are associated with sustainable construction techniques of new buildings in Kuwait and what possible methods industry professionals are currently using to overcome these perceived risks to avoid cost increases, time overruns, and long-term quality issues. The results of this research can be used by local and international industry professionals to develop a better understanding of the critical risk factors that are perceived to influence cost, time, and quality of construction projects. This understanding will lead to the development of risk management processes not only during the construction stages but also during the evolution of the design phase. Ultimately, by better understanding the risks associated with sustainable construction, the adoption rate of sustainable construction techniques and subsequent performance of the construction industry in the MENA will increase.

The three research questions are:

1. What sustainable construction risks do professionals in Kuwait believe have the highest probability of occurrence? 
2. What sustainable construction risks do professionals in Kuwait believe have the highest negative impact on project outcomes?

3. How do perceptions of sustainable construction risks differ between those working in private and public sectors, across project types (residential, commercial, and industrial), across professions (design engineer, contractor, sub-contractor), and across years of experience?

The results offer answers to these questions and the discussion offers relevant risk management strategies from past research to support future implementation of sustainable design and construction.

\section{Research Methodology}

The survey to professionals in the Kuwaiti construction industry consisted of two sections. The first section asked general information about the respondents such as their professional experience, type of organization, and their familiarity with construction techniques and technologies that contribute to sustainability. The purpose of this section was to gather descriptive statistics about the sample population. The second section included the 52 risks identified from the literature review.

Respondents were asked to "Please evaluate the probability of the following risks based on the outcomes of sustainable construction projects". Respondents were given a Likert scale $(1=$ very low probability and $5=$ very high probability). Respondents were asked again to "Please evaluate the impact of the following risks based on how they negatively affect the outcomes of sustainable construction projects." Respondents were given a Likert scale $(1=$ very low impact and $5=$ very high impact).

Prior to distribution of the survey, the survey was given to a focus group of five construction professionals in which each had 10 or more years of experience for content validity and to review and provide feedback about the questions. Changes made to the survey helped clarify the meaning of specific risks and certain wording was adjusted to more clearly communicate the meaning. For example, some of the risks were combined such as "design changes during construction" and "changes in work" since they were closely related to each other.

The survey was distributed to a national sample of professionals currently working in the construction industry in Kuwait. Professionals were selected randomly from a list of all construction companies in the country. A total of 195 surveys were sent to construction professionals and 131 surveys were returned ( $67 \%$ response rate).

\section{Risk Assessment}

The probability and impact of each risk was evaluated using a weighted score approach. This method was adopted from previous literature [43]. The weighted score approach in Equation (1) shows that, for every identified risk, the weighted score was calculated by adding the product of the number of respondents, $x$, with their corresponding selected Likert ranking, $r$.

$$
S_{W j}=\Sigma(x \times r)
$$

where $S_{W j}$ is the weighted score, $x$ is the number of respondents for each Likert rank, $r$ is the corresponding Likert scale ranking, and $j$ is a subscript index that represents $p$ for probability or $i$ for impact. A sample collected from the data in Table 2 shows that 17 out of 128 respondents ranked the identified risk element for "design changes during construction" with a Likert scale ranking of 5 (most probable) and the value $(17 \times 5=85)$ is the product. Similarly, nine individuals responded with a ranking of 1 (least probable) and the value $(9 \times 1=9)$ is the product. The total weighted score for this particular risk is 416, which is the summation of all the product values. Table 2 represents a sample on the probability of risk. The same equation was applied for the responses about the impacts of risk. 
Table 2. Sample calculation of weighted scores for risk probability of design changes during construction.

\begin{tabular}{|c|c|c|c|c|c|}
\hline \multirow{2}{*}{$\begin{array}{l}\text { Variable } \\
\text { Likert Scale }(r)\end{array}$} & \multicolumn{5}{|c|}{ Design Changes during Construction } \\
\hline & 1 & 2 & 3 & 4 & 5 \\
\hline $\begin{array}{l}\text { Number of respondents for each Likert } \\
\text { Scale ranking }(x)\end{array}$ & 9 & 21 & 40 & 40 & 17 \\
\hline $\begin{array}{l}\text { Number of respondents multiplied by } \\
\text { the Likert Scale ranking }(x \times r)\end{array}$ & 9 & 42 & 120 & 160 & 85 \\
\hline Weighted Score, $S_{W p}=\Sigma(x \times r)$ & & & 416 & & \\
\hline
\end{tabular}

The probability $P$ and impact $I$ are scaled weighted scores between 0 and 1 obtained by taking the percentage of the score with respect to maximum possible points for each category. In the sample calculation shown in Table 2, the maximum possible points for that risk is 640, which is obtained by multiplying the total number of respondents $(x=128)$ with the maximum Likert scale $(r=5)$. Equations (2) and (3) express this formulation below.

$$
\begin{gathered}
P=S_{W p} /(x \times 5) \\
I=S_{W i} /(x \times 5)
\end{gathered}
$$

where $S_{W p}$ is the weighted score for risk probability and $S_{W i}$ is the weighted score of risk impact.

Equation (4) was used to calculate the product of both probability and impact of occurrence. The purpose was to quantify the degree of risk. This equation was adopted from Reference [64].

$$
R=P \times I
$$

where $R$ is the degree of perceived risk measured between 0 and $1, P$ is the probability of the risk occurring measured between 0 and 1 , and $I$ is the degree of impact of the risk measured between 0 and 1. This method scales risks from high (close to 1 ) and low (close to 0 ) by considering both weighted probability and impact.

\section{Results}

The group of responses $(n=131)$ were contractors $(27 \%)$, owners/clients $(25 \%)$, construction consultants (18\%), and subcontractors and suppliers (30\%). Out of 131 surveyed, $45 \%$ indicated more than 10 years of experience in the construction industry, 29\% had between five to 10 years of experience, and $27 \%$ had less than five years of experience. Most of the respondents came from organizations that have more than 100 employees (53\%), 17\% from organizations that have 50-100 employees, and 30\% from organizations with less than 50 employees. Nearly $40 \%$ of respondents indicated their level of sustainability awareness was "poor" and only $19 \%$ perceived "good" awareness of sustainability concepts, procedures, and technologies. Nearly half of respondents $(47 \%)$ reported that the current percentage of construction projects that include sustainable construction practices or technologies in their organization was between $0 \%$ and $19 \%$. Half of the respondents $(50 \%)$ indicated they work with the public sector, $32 \%$ with the private sector, and $18 \%$ are quasi-public sectors. Details of the main research findings are listed in the sub-sections below.

\subsection{Risks That Have the Highest Probability and Impact of Occurrence}

To identify the risks that have the highest probability and highest impact of occurrence, the respondents were asked to evaluate the risks based on their probability and impact of occurrence in construction projects in Kuwait. Tables $3-5$ present the highest probability of perceived occurrence, expected impact, and their combined rankings (highest degree of perceived risk). Table 3 presents the 
top 10 risks with the highest perceived probability in ascending order based on their total weighted scores. Lack of public awareness about the benefits of sustainable design and construction and high costs of sustainable material and equipment are perceived as the risks having the highest probability of occurrence in construction projects in Kuwait.

Table 3. The top 10 risks based on the highest expected probability.

\begin{tabular}{|c|c|c|}
\hline \multicolumn{2}{|c|}{ Risks with Highest Probability of Occurrence } & \multirow{2}{*}{$\begin{array}{c}\text { Weighted Score, } S_{W p} \\
492\end{array}$} \\
\hline 1 & Lack of public awareness about the benefits for sustainability & \\
\hline 2 & High costs of sustainable materials \& equipment & 488 \\
\hline 3 & High initial sustainable construction costs & 472 \\
\hline 4 & Lack of market demand & 471 \\
\hline 5 & Lack of practical experience & 470 \\
\hline 6 & Lack of political support \& incentives & 455 \\
\hline 7 & Contractors inexperience with sustainable buildings & 448 \\
\hline 8 & Unavailability of specific equipment & 448 \\
\hline 9 & Unavailability of sustainable building materials in the market & 446 \\
\hline 10 & Uncertain governmental policies & 444 \\
\hline
\end{tabular}

Table 4 includes the top 10 risks with perceived high expected impact. Notably, contractors' inexperience with sustainable construction practices and technologies had the highest potential risk according to respondents. The second risk associated with adopting sustainable construction practices was design team inexperience, which was followed by the unavailability of sustainable building materials and lack of practical experience. These top four risks are $4 \%$ greater (about 20 points on average) in total weighted score compared to the bottom six. In other words, while these top 10 are close in value, the top four appear most critical for the respondents. Contractor's inexperience with sustainable construction is nearly $8 \%$ greater from the fifth-ranked highest cost of sustainable materials and equipment.

Table 4. The top 10 risks based on the highest expected impact.

\begin{tabular}{clc}
\hline Risks with Highest Impact of Occurrence & Weighted Score, $S_{W i}$ \\
\hline 1 & Contractors inexperience with sustainable construction & 519 \\
2 & Design team inexperience & 499 \\
3 & Unavailability of sustainable building materials in the market & 496 \\
4 & Lack of practical experience & 491 \\
5 & High costs of sustainable materials \& equipment & 481 \\
6 & Lack of political support \& incentives & 481 \\
7 & Design changes during construction & 479 \\
8 & Non-complying products \& materials & 479 \\
9 & Poor material quality & 476 \\
10 & Lack of public awareness & 471 \\
\hline
\end{tabular}

Table 5 presents the risks perceived as having a high degree of risk, $R$ (combined high probability and high impact). The degree of risk is considered high if the value is closer to 1 . The top five risks with similar total weighted scores (within $1 \%$ to $2 \%$ of each other), are high costs of sustainable materials and equipment, contractor's inexperience with sustainable construction, lack of practical experience, lack of public awareness, and high initial sustainable construction costs. The perceptions about higher upfront costs for sustainable materials and equipment are likely true in a country like Kuwait that is still early in the adoption of these materials and practices. However, increased awareness of the benefits may help offset or balance these higher up-front expenditures. 
Table 5. The top 10 combined high probability and impact risks.

\begin{tabular}{clc}
\hline Risks with Highest Degree of Perceived Risk & Degree of Perceived Risk, $\boldsymbol{R}$ \\
\hline 1 & High costs of sustainable materials \& equipment & 0.61 \\
2 & Contractor's inexperience with sustainable construction & 0.59 \\
3 & Lack of practical experience & 0.58 \\
4 & Lack of public awareness & 0.579 \\
5 & High initial sustainable construction costs & 0.575 \\
6 & Unavailability of sustainable building materials in the market & 0.55 \\
7 & Lack of market demand & 0.548 \\
8 & Lack of political support \& incentives & 0.547 \\
9 & Cost estimation inaccuracy & 0.536 \\
10 & Difficulty in the selection of subcontractors who provide sustainable & 0.532 \\
\hline
\end{tabular}

\subsection{Risk Categories that Have the Highest Probability and Impact of Occurrence}

The risk categories from Table 1 with the average highest perceived probability were external risks (e.g., public awareness and knowledge, government incentives, market demand) (mean Likert score $=3.7 ; 1=$ very low probability $/$ impact and $5=$ very high probability $/$ impact $)$ and finance-related risks (e.g., cost of sustainable materials, schedule delays, payback period) (mean Likert score $=3.5$ ). Scores were determined using the mean value of the Likert scale responses to each of the individual risks. An average of the Likert scale was calculated to compare between categories where there are several risks in each category, which can reveal the statistical differences. The perceived probability of risk occurrence in all risk categories was above average (more than 50\%, mean scores above 3.0) except for the Certification category (mean score less than 3.0). The difference in mean scores between the categories (probability and impact) was statistically significant $(p<0.001)$. The one-way ANOVA test was used since it can determine the statistical difference between the means of two or more independent groups. The mean scores of the probability of each risk category are shown in Figure 1.

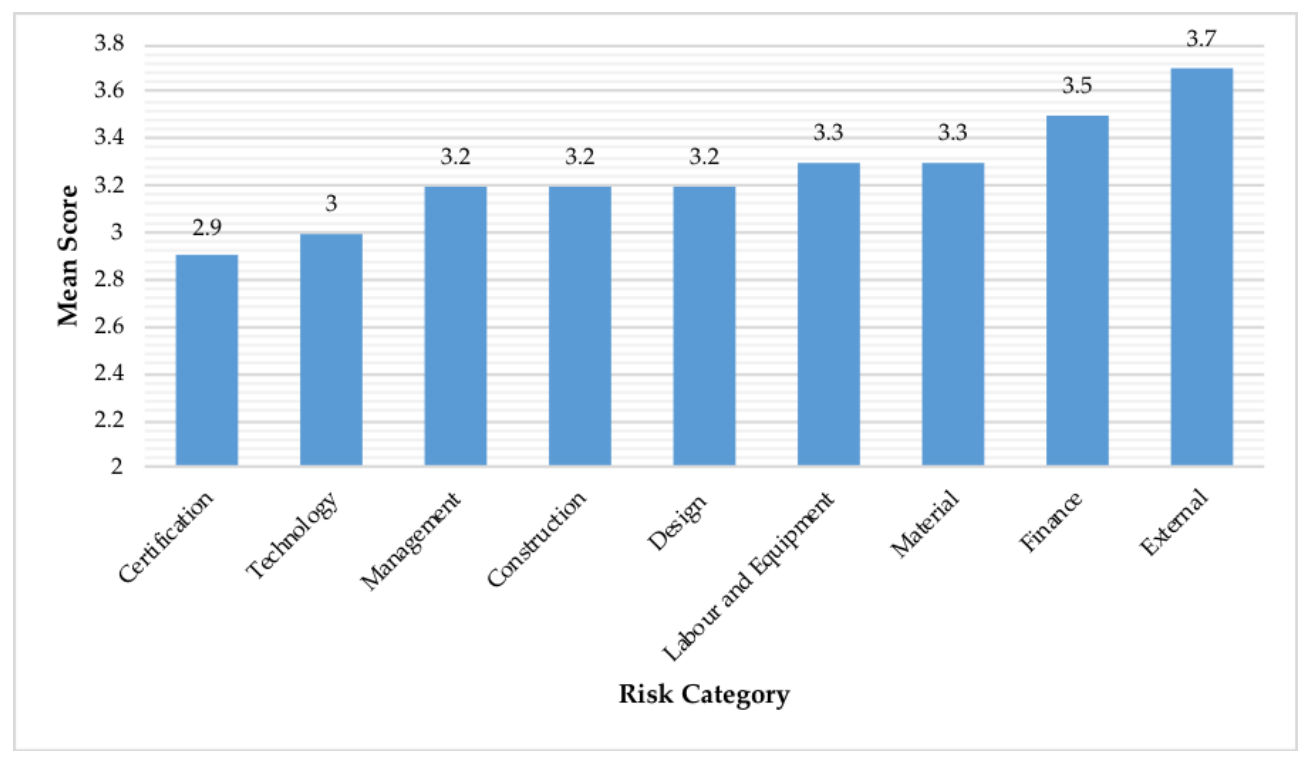

Figure 1. Mean scores for probability of risk categories (scores range from 1 to 5).

Respondents perceive risk impacts related to the materials such as unavailability of sustainable building materials, uncertainty of quality, and change orders for material as the highest possible impact for project outcomes. Design risks were also perceived as having a high potential impact including design changes during construction, design defects, and inexperience with sustainable 
design. The perceived risk impact in all risk categories was above average (more than $50 \%$, mean scores above 3.0). The mean scores of the impact of each risk category are shown in Figure 2.

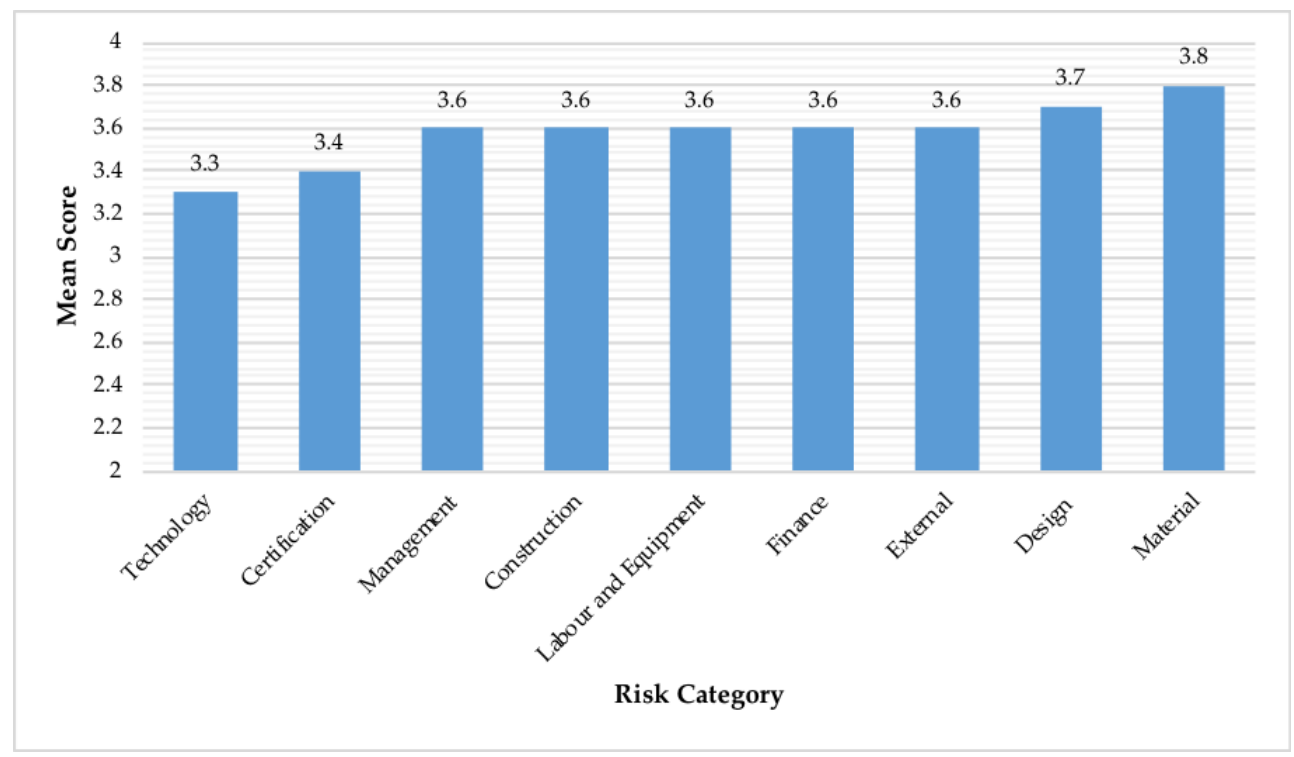

Figure 2. Mean scores for impact of risk categories (scores range from 1 to 5).

The results of each of the probability and impact of risk categories are significantly different. However, the top five categories are similar. This means the nine associated risk categories include risks associated with material, design, external factors, finance, labor, and equipment. The risks have the highest probability of occurrence and would cause the greatest impact on project outcomes. In terms of both probability and impact, the certification and technology categories are of the least concern for the respondents.

\subsection{Perceptions of Construction Professionals in the Private Sector Compared to the Public Sector}

The findings indicate no significant differences in the mean scores for all risk categories between the different titles of the professionals (project manager, site engineer, or architect), their practical experience (years), or their typical project types (residential, commercial, and industrial).

The only factor with a significant difference in response was whether their client base was private or public. The mean scores for the perceived probability of risk between private and public sectors were significantly different in the following categories: design $(p=0.004)$, construction $(p<0.001)$, management $(p=0.017)$, finance $(p=0.013)$, and technology $(p=0.013)$. Professionals working with the public sector perceive higher probabilities of risk in construction, management, finance, and technology but lower probabilities of risk compared to the private sector related to design. Risks associated with management were perceived as significantly higher by the public sector $(p=0.023)$ than the private sector. The other four categories had similar perceptions between respondents with public and private clients. The one-way ANOVA test was used to generate the $p$-values. Table 6 summarizes these results. 
Table 6. Comparison of risk categories by sector types.

\begin{tabular}{|c|c|c|c|c|c|}
\hline \multirow{2}{*}{ Risk Categories } & \multicolumn{2}{|c|}{ Public Sector } & \multicolumn{2}{|c|}{ Private Sector } & \multirow{2}{*}{$p$-Value } \\
\hline & Mean & (SD) & Mean & (SD) & \\
\hline \multicolumn{6}{|l|}{ Design related risks } \\
\hline Probability of risk occurrence & 3.2 & $(0.7)$ & 3.5 & $(0.6)$ & 0.004 \\
\hline Expected impact of risk & 3.8 & $(0.8)$ & 3.7 & $(0.6)$ & 0.905 \\
\hline \multicolumn{6}{|l|}{ Construction related risks } \\
\hline Probability of risk occurrence & 3.4 & $(0.7)$ & 3.1 & $(0.7)$ & $<0.001$ \\
\hline Expected impact of risk & 3.7 & $(0.8)$ & 3.6 & $(0.7)$ & 0.477 \\
\hline \multicolumn{6}{|l|}{ Management related risks } \\
\hline Probability of risk occurrence & 3.4 & $(0.7)$ & 3.0 & $(0.8)$ & 0.017 \\
\hline Expected impact of risk & 3.7 & $(0.6)$ & 3.3 & $(0.7)$ & 0.023 \\
\hline \multicolumn{6}{|l|}{ Finance related risks } \\
\hline Probability of risk occurrence & 3.7 & $(0.8)$ & 3.3 & $(0.7)$ & 0.013 \\
\hline Expected impact of risk & 3.7 & $(0.8)$ & 3.7 & $(0.7)$ & 0.560 \\
\hline \multicolumn{6}{|l|}{ Technology related risks } \\
\hline Probability of risk occurrence & 3.3 & $(1.0)$ & 2.7 & $(0.9)$ & 0.013 \\
\hline Expected impact of risk & 3.5 & $(1.0)$ & 3.2 & $(0.9)$ & 0.142 \\
\hline
\end{tabular}

The difference in perceived probability and impact between construction professionals with public sector clients and private sector clients appear to relate to their level of awareness to sustainability in Kuwait. Between the two sectors, the private sector has a higher level of perceived sustainability awareness, which is illustrated in Figure 3. None of the respondents (whether public or private) believe that their knowledge of sustainable construction is "very good".

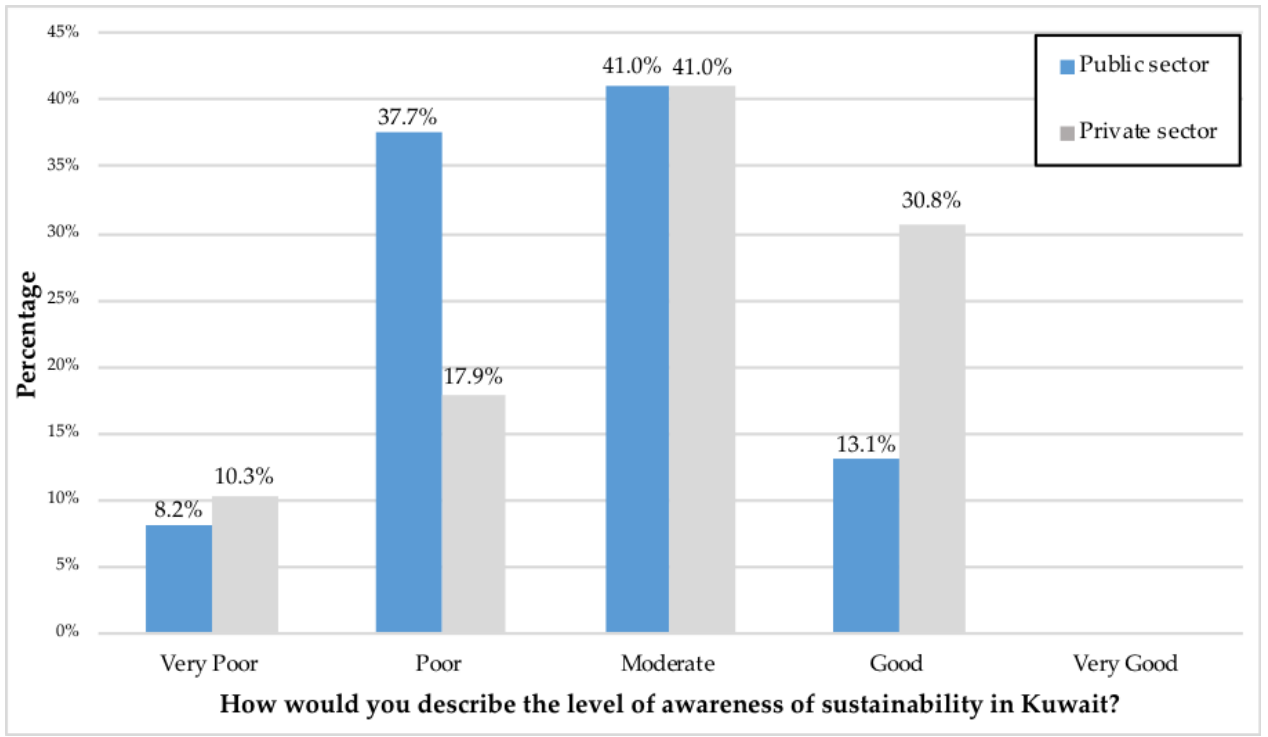

Figure 3. Level of awareness about sustainability among construction professionals in Kuwait that work with clients from the private and public sectors.

\section{Discussion}

Construction professionals in Kuwait that serve clients in the private sector appear to perceive less probability of risks related to construction, management, and finance when adopting sustainable techniques and technologies. These results are somewhat surprising compared to other regions and countries like the United States and Europe where government institutions were the early adopters of sustainable construction, which mandates the use of LEED and BREEAM, respectively, nearly two decades ago. The private sector may contribute to more innovative techniques and technologies with 
contract structures that help distribute risks among multiple stakeholder groups. The culture and ability to innovate because of distributed risk may explain why these differences occur between client types [64].

Another reason for the differences in perceptions between construction professionals that work with public or private sector clients is that the private sector in Kuwait tends to hire more non-Kuwaitis than the public sector. Industry professionals hired from outside of the country might bring experience and understanding of sustainability. The public sector predominately hires Kuwaiti citizens who, due to the currently low adoption rate of sustainable design and construction, are less likely familiar with sustainability principles and applications for construction [65]. This gap in sustainable awareness and experience may contribute to why construction professionals that work with private sector clients are less concerned about probabilities of risk related to sustainability compared to those that represent clients from the public sector.

Even with respondents in the private sector indicating "moderate" to "good" understanding of sustainable construction, risks associated with designer and contractors' inexperience with sustainable construction rank highest and could negatively impact project outcomes. A tested solution to overcome these barriers is clients or project owners that recognize the benefits of incorporating sustainable design and construction techniques into their buildings and infrastructure and are motivated to request contractors and design teams with experience in sustainable projects [7]. Another strategy is through contracting sustainability experts. Experts may help general contractors recognize specialty issues and can help facilitate new markets or products that meet sustainability criteria. For example, risks identified in the results with high probability and impact such as unavailability of specific materials and equipment in the market can occur due to unforeseen procurement issue and lag times. Experts can help estimate additional times, delays, and scheduling issues that may arise because they have experience with these products [26].

Respondents also recognize the high costs of sustainable materials and equipment as high in probability and negative impact on future projects that adopt sustainability. Since this industry and region are new toward adopting sustainable construction, the higher cost of materials and equipment is similar to the greater cost of sustainable buildings in the United States and Europe nearly two decades ago when they were early in the adoption phase [9]. To bridge this gap, sharing knowledge across suppliers about what new standards and requirements mean and must be able to document is a possible strategy to reduce perceived risks over time [26,55]. Toyota, for example, groups suppliers together that use similar production processes to ensure that the information can be shared between them and is relevant for all [66]. Other interventions can be applied such as education and awareness programs for engineering professionals and public awareness programs. If these approaches are implemented, the major obstacle of lack of information on sustainable construction can be overcome.

Similar to higher costs of materials and equipment, broad categories of risk related to external factors such as the lack of market demand and lack of regional incentives as well as financial factors such as payback period and performance uncertainties are of greatest concern for these construction professionals. Prior research finds that material scarcity and availability to meet sustainability standards is a predominant factor and can directly impact costs [4]. Contingency premiums can work to reduce the cost for contractors and shift risk to clients and project owners [67].

Inherently, projects that include design and construction techniques for sustainability will incur more risks in the Kuwait construction industry because of the novelty and lack of experience among construction professionals. Traditional risk management strategies such as coordination with subcontractors, increasing workforce and equipment, producing programs using subjective decisions, and producing schedules that offer realistic resource procurement timelines [43] are helpful in traditional projects but may fall short when adopting sustainable construction practices. Achieving project goals for sustainability will require new technologies and strategies unfamiliar to the current workforce. Risk management programs should begin by addressing the barriers identified in the results of this paper. Regular training can help address the lack of awareness [26]. Innovative contract 
structures and employing those with experience in sustainable design and construction, especially in the public sector, can also help. The upfront cost is a real barrier especially for early adopters [60]. More focus on the benefits of sustainable design and construction may help balance the perceived high cost by educating suppliers and subcontractors and creating a network of professionals that supply the resources and materials that meet the standards for more sustainable materials.

Incorporating more nuanced techniques through behavioral science may also have an effect on construction professionals across cultures and regions, which are worth exploring [8]. For example, representing risks as embedded characteristics of engineering options can change the propensity of decision makers to take risks [68]. Framing risks as loss or gain can raise uncertainty awareness of decision-makers and can nudge construction professionals away from riskier, more uncertain options and towards less risky and certain options [69]. Including a feasibility example or a role model project for construction professionals to use as a guide can encourage higher levels of sustainability achievement [70]. However, these behavioral interventions have not been tested across cultures or with those less aware of sustainable design and construction.

The strength of the effect of framing interventions related to risk is limited to the values of the decision maker [71]. In other words, the effects of framing are larger when the concern or knowledge is low [72]. Participants with relevant experiences and more information on the subject may answer differently than those with limited awareness [12]. Therefore, professionals in Kuwait may be more influenced by framing or other behavioral interventions about risk than professionals in the United States or parts of Europe that have decades of experience and formed heuristics about sustainable construction. Future research can now begin to explore these possible interventions to shift perceptions and nudge contractors to incorporate sustainable design and construction techniques and technologies into building and infrastructure projects.

There are a few limitations to this study. First, the list of synthesized risks is not a comprehensive one since it includes risks from prior research published within the last 10 years only. The rationale for this choice is because risk management has evolved substantially over the last decade, but there could be some sustainability risks identified earlier or not included in this list that the construction industry faces today. Second, literature about sustainable construction risks in Kuwait and the MENA region is limited. There were only a few direct sources of reference from those countries. However, risks identified globally have been used in the literature review. The professionals did perceive many of these risk elements as having a high probability and impact of occurrence in Kuwait. Regardless of these limitations, this research identifies perceived risks in the Kuwaiti construction industry, which is a step forward in understanding and adopting more sustainable construction techniques.

\section{Conclusions}

The limited adoption rate for sustainable design and construction practices in the MENA region especially Kuwait is troublesome given that per capita residents in this region of the world produce $53 \%$ more greenhouse gas emissions than in the United States [22]. The lack of experience in sustainable construction appears to increase perceived risks among construction professionals. Industry professionals perceive that most risks of sustainable construction have high probabilities and impacts of risk occurrence. This perceived risk and higher cost for sustainable materials and equipment likely act as a barrier to adoption of new techniques and technologies. Other perceived risks include the lack of public awareness and practical experience, which are both related to knowledge and expertise. Differences in perceptions between sector types are significant. Construction professionals with clients in the private sector are less concerned with the probabilities and impacts of risk compared to the public sector specifically in risks related to finance, management, construction, and technology. Interestingly, project managers, site engineers, and architects showed no variation in their risk perceptions.

However, as important as the high probability and impact risks, are those with low probability and low impact. Time focused on these risks are potentially limiting the attention to risk with much higher negative effects. The construction professionals represented in this research overwhelming 
agreed risks related to technology and sustainability certification were low. Several sustainable risk management strategies can encourage more sustainable adoption and reduction of perceived risk. Contingency plans and shared risks with innovative contract structures can work to reduce the cost for contractors [57]. Sustainability experts can also help facilitate new markets or products that meet sustainability criteria and sharing knowledge across suppliers and subcontracts can spur industry support that, over time, reduces procurement costs and time $[26,66]$. Behavioral science approaches such as framing risks as gains in value instead of a loss or providing a role model project for teams to follow may also help nudge the industry forward in the adoption of sustainable construction techniques. Future research can now begin to measure the effect of new risk management strategies and behavioral interventions to change the perceptions identified in this paper and measure the adoption rate of sustainability in Kuwait and the entire MENA region [73].

Author Contributions: D.I. took part in conceptualization, formal analysis, methodology, and original draft writing. T.S. conducted results validation, writing the review, and editing the manuscript.

Conflicts of Interest: The authors declare no conflicts of interest.

\section{References}

1. Holden, E.; Linnerud, K.; Banister, D. The Imperatives of Sustainable Development. Sustain. Dev. 2017, 25, 213-226. [CrossRef]

2. Hill, R.C.; Bowen, P.A. Sustainable construction: Principles and a framework for attainment. Constr. Manag. Econ. 1997, 15, 223-239. [CrossRef]

3. Reed, W.G.; Gordon, E.B. Integrated design and building process: What research and methodologies are needed? Build. Res. Inf. 2000, 28, 325-337. [CrossRef]

4. Klotz, L.; Horman, M. Counterfactual Analysis of Sustainable Project Delivery Processes. J. Constr. Eng. Manag. 2010, 136, 595-605. [CrossRef]

5. Beamish, T.D.; Biggart, N. Social Heuristics: Decision Making and Innovation in a Networked Production Market; Social Science Research Network: Rochester, NY, USA, 2010.

6. Klotz, L.; Mack, D.; Klapthor, B.; Tunstall, C.; Harrison, J. Unintended anchors: Building rating systems and energy performance goals for U.S. buildings. Energy Policy 2010, 38, 3557-3566. [CrossRef]

7. Demaid, A.; Quintas, P. Knowledge across cultures in the construction industry: Sustainability, innovation and design. Technovation 2006, 26, 603-610. [CrossRef]

8. Shealy, T.; Klotz, L. Choice Architecture as a Strategy to Encourage Elegant Infrastructure Outcomes. J. Infrastruct. Syst. 2017, 23, 4016023. [CrossRef]

9. Ahn, Y.H.; Pearce, A.R. Green Construction: Contractor Experiences, Expectations, and Perceptions. J. Green Build. 2007, 2, 106-122. [CrossRef]

10. Samuelson, W.; Zeckhauser, R. Status quo bias in decision making. J. Risk Uncertain. 1988, 1, 7-59. [CrossRef]

11. Kahneman, D.; Knetsch, J.L.; Thaler, R.H. Anomalies: The Endowment Effect, Loss Aversion, and Status Quo Bias. J. Econ. Perspect. 1991, 5, 193-206. [CrossRef]

12. Fischhoff, B.; Kadvany, J.D. Risk: A Very Short Introduction; Oxford University Press: Oxford, UK; New York, NY, USA, 2011; ISBN-13 9780199576203; ISBN-10 0199576203.

13. Yang, R.; Zou, P.; Wang, J. Modelling stakeholder-associated risk networks in green building projects. Int. J. Proj. Manag. 2015, 34. [CrossRef]

14. Andi. The importance and allocation of risks in Indonesian construction projects. Constr. Manag. Econ. 2006, 24, 69-80. [CrossRef]

15. Qian, Q.K.; Chan, E.H.W.; Khalid, A.G. Challenges in Delivering Green Building Projects: Unearthing the Transaction Costs (TCs). Sustainability 2015, 7, 3615-3636. [CrossRef]

16. Bryde, D.J.; Volm, J.M. Perceptions of owners in German construction projects: Congruence with project risk theory. Constr. Manag. Econ. 2009, 27, 1059-1071. [CrossRef]

17. Robichaud, L.B.; Anantatmula, V.S. Greening Project Management Practices for Sustainable Construction. J. Manag. Eng. 2011, 27, 48-57. [CrossRef]

18. Cidell, J. Building Green: The Emerging Geography of LEED-Certified Buildings and Professionals. Prof. Geogr. 2009, 61, 200-215. [CrossRef] 
19. Zou, P.X.W.; Zhang, G.; Wang, J. Understanding the key risks in construction projects in China. Int. J. Proj. Manag. 2007, 25, 601-614. [CrossRef]

20. AlSanad, S. Awareness, drivers, actions, and barriers of sustainable construction in Kuwait. Procedia Eng. 2015, 118, 969-983. [CrossRef]

21. Omran, A.; Mohd Shafie, M.W.; Osman Kulaib, H.M. Identifying Environmental Risk in Construction Projects in Malaysia: Stakeholder Perspective. Ann. Fac. Eng. Hunedoara 2015, 13, 89-92.

22. The World Bank Kuwait Data. Available online: http:/ / data.worldbank.org/country/kuwait (accessed on 7 February 2017).

23. World Energy Council World Energy Perspective: Energy Efficiency Policies-What Works and What Does Not. Available online: https:/ / www.worldenergy.org/wp-content/uploads/2013/09/WEC-EnergyEfficiency-Policies-executive-summary.pdf (accessed on 11 December 2017).

24. Darwish, M.A.; Al-Awadhi, F.M.; Darwish, A.M. Energy and water in Kuwait Part I. A sustainability view point. Desalination 2008, 225, 341-355. [CrossRef]

25. Kuwait Central Statistical Bureau. Available online: http://www.csb.gov.kw/Socan_Statistic_EN.aspx?ID= 18 (accessed on 13 October 2016).

26. Zou, P.X.W.; Couani, P. Managing risks in green building supply chain. Arch. Eng. Des. Manag. 2012, 8, 143-158. [CrossRef]

27. AlSanad, S.; Gale, A.; Edwards, R. Challenges of sustainable construction in Kuwait: Investigating level of awareness of Kuwait stakeholders. World Acad. Sci. Eng. Technol. Int. J. Environ. Chem. Ecol. Geol. Geophys. Eng. 2011, 5, 753-760.

28. Eichholtz, P.; Kok, N.; Quigley, J.M. Doing Well by Doing Good? Green Office Buildings. Am. Econ. Rev. 2010, 100, 2492-2509. [CrossRef]

29. Mang, P.; Haggard, B. Regenesis Regenerative Development and Design: A Framework for Evolving Sustainability. Available online: http:/ / www.wiley.com/WileyCDA/WileyTitle/productCd-1118972864. html (accessed on 1 September 2017).

30. Rafindadi, A.D.; Mikić, M.; Kovačić, I.; Cekić, Z. Global Perception of Sustainable Construction Project Risks. Procedia Soc. Behav. Sci. 2014, 119, 456-465. [CrossRef]

31. Kibert, C.J. Sustainable Construction: Green Building Design and Delivery; John Wiley \& Sons: New York, NY, USA, 2016; ISBN 978-1-119-05517-4.

32. Harris, N.; Shealy, T.; Klotz, L. Choice Architecture as a Way to Encourage a Whole Systems Design Perspective for More Sustainable Infrastructure. Sustainability 2016, 9, 54. [CrossRef]

33. Lovins, A.; Bendewald, M.; Kinsley, M.; Bony, L.; Hutchinson, H.; Pradhan, A.; Sheikh, I.; Acher, Z. Factor Ten Engineering Design Principles. Available online: http:/ / www.10xe.orwww.10xe.org/Knowledge-Center/ Library/2010-10_10xEPrinciples (accessed on 18 May 2018).

34. Yardi, R.; Archambault, T.; Wang, K.; Eubank, H. Home Energy Briefs: \#9 Whole System Design. Available online: http://www.10xe.orwww.10xe.org/Knowledge-Center/Library/2004-21_ HEB9WholeSystemDesign (accessed on 18 May 2018).

35. Blizzard, J.L.; Klotz, L. A framework for sustainable whole systems design. Des. Stud. 2012, 33, 456-479. [CrossRef]

36. Smith, N.J.; Merna, T.; Jobling, P. Managing Risk: In Construction Projects; John Wiley \& Sons: New York, NY, USA, 2009; ISBN 978-1-4051-7274-5.

37. Westland, J. The Project Management Life Cycle: A Complete Step-By-Step Methodology for Initiating, Planning, Executing \& Closing a Project Successfully; Kogan Page Publishers: London, UK, 2007; ISBN 978-0-7494-4808-0.

38. Keller, C.; Siegrist, M.; Gutscher, H. The Role of the Affect and Availability Heuristics in Risk Communication. Risk Anal. 2006, 26, 631-639. [CrossRef] [PubMed]

39. Tversky, A.; Kahneman, D. Choices, values, frames. Am. Psychol. 1984, 39, 341-350. [CrossRef]

40. Hwang, B.; Ng, W.J. Are Project Managers Ready for Green Construction?-Challenges, Knowledge Areas, and Skills. In Proceedings of the CIB World Building Congress 2013, St Lucia, QLD, Australia, 5-9 May 2013.

41. Kerur, S.; Marshall, W. Identifying and managing risk in international construction projects. Int. Rev. Law 2012, 1. [CrossRef]

42. Pearce, A.R. Sustainable capital projects: Leapfrogging the first cost barrier. Civ. Eng. Environ. Syst. 2008, 25, 291-300. [CrossRef] 
43. Kartam, N.A.; Kartam, S.A. Risk and its management in the Kuwaiti construction industry: A contractors' perspective. Int. J. Proj. Manag. 2001, 19, 325-335. [CrossRef]

44. El-Sayegh, S.M. Risk assessment and allocation in the UAE construction industry. Int. J. Proj. Manag. 2008, 26, 431-438. [CrossRef]

45. Jarkas, A.M.; Haupt, T.C. Major construction risk factors considered by general contractors in Qatar. J. Eng. Des. Technol. 2015, 13, 165-194. [CrossRef]

46. Altoryman, A.S. Identification and Assessment of Risk Factors Affecting Construction Projects in the Gulf Region: Kuwait and Bahrain. Ph.D Thesis, The University of Manchester, Manchester, UK, 30 April 2014.

47. Van Buiten, M.; Hartmann, A. Public-private partnerships: Cognitive biases in the field. In Proceedings of the Engineering Project Organization (EPOC 2013), Winter Park, CO, USA, 9-11 July 2013.

48. Shen, L.Y. Project risk management in Hong Kong. Int. J. Proj. Manag. 1997, 15, 101-105. [CrossRef]

49. Douglas, P.M. Risk and Blame; Routledge: London, UK, 2013; ISBN 978-1-136-49004-0.

50. Alvaro, S.-C.; Alfalla-Luque, R.; Irimia Diéguez, A.I. Risk Identification in Megaprojects as a Crucial Phase of Risk Management: A Literature Review. Proj. Manag. J. 2017, 47, 75.

51. Hwang, B.-G.; Ng, W.J. Project management knowledge and skills for green construction: Overcoming challenges. Int. J. Proj. Manag. 2013, 31, 272-284. [CrossRef]

52. Bal, M.; Bryde, D.; Fearon, D.; Ochieng, E. Stakeholder Engagement: Achieving Sustainability in the Construction Sector. Sustainability 2013, 5, 695-710. [CrossRef]

53. Tollin, H.M. Green Building Risks: It's Not Easy Being Green. Environ. Claims J. 2011, 23, 199-213. [CrossRef]

54. Swan, L.G.; Ugursal, V.I. Modeling of end-use energy consumption in the residential sector: A review of modeling techniques. Renew. Sustain. Energy Rev. 2009, 13, 1819-1835. [CrossRef]

55. O'Connor, H. Architect's Professional Liability Risks in the Realm of Green Buildings. Available online: https:/ / uk.perkinswill.com/research/architects-professional-liability-risks-in-the-realm-of-greenbuildings.html (accessed on 28 April 2018).

56. Hwang, B.-G.; Tan, J.S. Green building project management: Obstacles and solutions for sustainable development. Sustain. Dev. 2012, 20, 335-349. [CrossRef]

57. Azizi, M.; Fassman, E.; Wilkinson, S. Risks Associated in Implementation of Green Buildings. Available online: http:/ / www.thesustainabilitysociety.org.nz/conference/2010/papers/Mokhtar-Azizi-FassmanWilkinson.pdf (accessed on 4 May 2017).

58. Aminu Umar, U.; Khamidi, D.M.F. Determined the Level of Green Building Public Awareness: Application and Strategies. In Proceedings of the International Conference on Civil, Offshore and Environmental Engineering, Kuala Lumpur, Malaysia, 12-14 June 2012.

59. Lam, P.T.; Chan, E.H.; Poon, C.S.; Chau, C.K.; Chun, K.P. Factors affecting the implementation of green specifications in construction. J. Environ. Manag. 2010, 91, 654-661. [CrossRef] [PubMed]

60. Turner Construction 2014 Green Building Market Barometer. Available online: http://www. turnerconstruction.com/download-document/turner2014greenbuildingmarketbarometer.pdf (accessed on 22 April 2017).

61. Arashpour, M.; Arashpour, M. A collaborative perspective in green construction risk management. In Proceedings of the 37th Annual Conference of Australasian Universities Building Educators Association (AUBEA), Sydney, Australia, 4-6 July 2012; UTS Publishing/University of New South Wales: Sydney, Australia, 2012; pp. 1-11.

62. Anderson, M.K.; Bidgood, J.K.; Heady, E.J. Hidden Legal Risks of Green Building. Fla. Bar J. 2010, 84, $35-41$.

63. Dagdougui, H. Decision Support Systems for Sustainable Renewable Energy Systems and Hydrogen Logistics: Modelling, Control and Risk Analysis. Ph.D. Thesis, École Nationale Supérieure des Mines de Paris, Università degli studi di Genova, Genova, Italy, 2011.

64. Zhi, H. Risk management for overseas construction projects. Int. J. Proj. Manag. 1995, 13, 231-237. [CrossRef]

65. Gulseven, O. Challenges to Employing Kuwaitis in the Private Sector. Available online: http://www.oxgaps. org/files/analysis_gulseven.pdf (accessed on 19 May 2017).

66. Dyer, J.H.; Nobeoka, K. Creating and Managing a High-Performance Knowledge-Sharing Network: The Toyota Case. Strateg. Manag. J. 2000, 21, 345-367. [CrossRef]

67. Lapinski, A.R.; Horman, M.J.; Riley, D.R. Lean Processes for Sustainable Project Delivery. J. Constr. Eng. Manag. 2006, 132, 1083-1091. [CrossRef] 
68. Van Buiten, M.; Hartmann, A.; van der Meer, J.P. Nudging for smart construction: Tackling uncertainty by changing design engineers' choice architecture. In Proceedings of the Engineering Project Organization Conference 2016, Cle Elum, DC, USA, 28-30 June 2016.

69. Shealy, T.; Ismael, D.; Hartmann, A.; van Buiten, M. Removing Certainty from the Equation: Using Choice Architecture to Increase Awareness of Risk in Engineering Design Decision Making. In Proceedings of the Engineering Project Organization Conference, Stanford, CA, USA, 5-7 June 2017.

70. Harris, N.; Shealy, T.; Klotz, L. How Exposure to "Role Model" Projects Can Lead to Decisions for More Sustainable Infrastructure. Sustainability 2016, 8, 130. [CrossRef]

71. McClure, J.; White, J.; Sibley, C.G. Framing effects on preparation intentions: Distinguishing actions and outcomes. Disaster Prev. Manag. Int. J. 2009, 18, 187-199. [CrossRef]

72. Newman, C.L.; Howlett, E.; Burton, S.; Kozup, J.C.; Heintz Tangari, A. The influence of consumer concern about global climate change on framing effects for environmental sustainability messages. Int. J. Advert. 2012, 31, 511-527. [CrossRef]

73. Tang, O.; Nurmaya Musa, S. Identifying risk issues and research advancements in supply chain risk management. Int. J. Prod. Econ. 2011, 133, 25-34. [CrossRef]

(C) 2018 by the authors. Licensee MDPI, Basel, Switzerland. This article is an open access article distributed under the terms and conditions of the Creative Commons Attribution (CC BY) license (http:/ / creativecommons.org/licenses/by/4.0/). 